\title{
African Legacies in Pacific Colombian Music: A Synthesis
}

\author{
Carlos A. Arcila \\ arcila.carlos@gmail.com
}

\begin{abstract}
Essentially, a summary of extensive and intensive research with several Afro-Colombian musicians who live in Colombia's Pacific Coastal region, this article is presented as two major complementary components. Firstly, a multimedia, predominantly, with original recorded music and photographs, as importantly, a separate text with explanatory discussions and analyses, both perform key roles and occupy centre stage.

The article demonstrates in audible and visible terms the pervasive and living influences of Africa on the region's cultures. To do so, the article concentrates on an explicit analysis of the currulao music. It traces the music's origins to the cimarrones who fled the plantations and mines to live in the mountainous, tropical interior. The research shows that the formerly, enslaved Africans drew on their cultures, for example, their drums and music to accommodate and resist the insistent and usually, enforced colonizing activities of the Roman Catholic missionaries.
\end{abstract}

\section{Prelude}

In this article, emphasis is placed on a reiterative, self-directed, and yet, guided experiential learning process of (i) listening to and immersing one's self in the music. Followed with (ii) a close reading of the explanatory text. Perhaps, (iii) returning to the music. (iv) re-reading, the text in order to, identify additional understandings and nuances in the music.

To begin: go to the link identified below, in order to access, the original work: "A Multimedia Stylistic Analysis of the Marimba de Chonta, Guapi, Cauca, Colombia".

Follow the instructions and cues. Wait for a little for your computer to access the specific musical files. The soft currulao sounds played by the musicians will transport you to the Pacific Colombian coast (1).

Estamos listos? Síganme a Colombia.

The hot link to Colombia's Pacific coast music

http://marimbadechonta.com/ 


\section{The explanatory narrative of the Marimba}

The currulao, the focus of this discussion, is the main musical style of the Pacific Colombian coastal zone. The marimba de chonta is the principal instrument in currulao music. If you listen again to the music, several explicit and subtle musical differences can be noticed and heard among performers playing the same traditional currulao music on the marimba de chonta but with different approaches and interpretations.

Living principally in the municipalities of Guapi, Zuáres, Timbiqui, and Lopez de Micay, Department of Cauca; Mosquera, and Barbacoas, in the Departament of Nariño; Bahía Málaga, Buenaventura, and Cali, in the Department of Valle del Cauca, the musicians to whom you have listened, have inherited a rich cultural legacy from several African, Spanish and Amerindian cultures. The article presents evidence that aspects of the African heritage have survived and are alive in the music and other parts of the culture. Through the music, stories of cultural retention and resiliency of the Afro-Colombian people have been told, and re-told innumerable times, by oral historians and musicians.

The main purpose of the larger study is to demonstrate the features of the currulao as played by several performers. The music is catalogued on the multimedia, which you have heard. The multimedia includes twenty examples of different performers playing their particular versions of the currulao repertoire on the marimba.

In the larger research study, examples of the music are transcribed, annotated and analyzed meticulously. The transcriptions and annotations are approximations using western notations to compare the distinctive characteristics of each of the 20 marimba performances. The study includes detailed information about the harmonic, melodic, and rhythmic materials, which are based on the recordings, videos, and transcriptions made by the author in 2005 and 2006 in the city of Guapi, the port of Buenaventura, and Cali $(2,3)$. Some consideration is also given in the analysis to the materials and construction of the marimba de chonta (4).

This article concentrates on the music of the multimedia; summarizes the music's historical and geographical contexts; explains the significance of the different types of music played for secular, religious, life changing and everyday events. Finally, the article questions the long term future of the music.

\section{Historical context}

For several hundred years, as a result of colonization, Colombian communities have developed a remarkable musical heritage. In Pacific Colombia, people from three different cultures: Spanish, African and Indigenous Amerindian met, converged and have been transformed within specific historical, political, social, economic and cultural conditions. Under the colonialist situation, Spaniards brought African slaves to Colombia to replace the indigenous manual labourers. Within a relatively short period, most Amerindians, like indigenous people in many European colonies, died in sizeable numbers at alarming and accelerated rates. This was due to inhumane working conditions and exposure to European diseases (Ramón, 2010, p. 15).

Cultural and Pedagogical Inquiry, Fall 2016, 8(2), pp. 72-82

ISSN 1916-3460 @ 2016 University of Alberta

http://ejournals.library.ualberta.ca/index.php/cpi/index 
Over time, African slaves lived with Spanish and indigenous people and have produced a new creole people (the Afro-Colombians). Various elements of the African cultures such as, languages and music slowly penetrated the evolving local cultural life. In Pacific Colombia, "African slaves reproduced their own native instruments with materials found in their new residences, ... they recreated their music, religious rites and dances" (Ramón, 2010, p. 15). The marimba de chonta in particular, is derived from the African xylophone or balaphone (See explanation, endnote 4).

African influenced music and culture have always played very important roles in AfroColombian communities. Knowledge and culture have been transmitted orally since the African slaves were brought from the Occidental Sudan, Congo, Guinea Coast, and the desert zone coming to la Nueva Granada (Colombia) in the XVII century. The Yoruba and Bantu were the most widespread of the African cultures transported to colonial Colombia.

Groups of African slaves were brought by force to the coastal regions by Spaniards to work in agriculture and mining (Lopez, 1980, p. 69). Many of them escaped from the plantations or from mining quadrilles. They penetrated the tropical jungle and the rugged, remote interior in order to establish cimarrone communities, moving as far as possible, from the Spanish plantations and mines. Interestingly, the cimarrones, status of freedom and the geographical isolation of their communities, facilitated the preservation of key African traditions.

In 1759, once the Spanish dominance was finished, and Cartagena de Indias began to decline in importance, as a major port for the slave trade, another slave trade was established and conducted in Chocó. At that time, there were 447 slaves with African last names from different African cultures: 139 Minas, 80 Congos, 47 Araras, 45 Carabalies, 30 Chambas, 25 Chalas, 23 Setres, 21 Mandingas, 17 Popos and 10 Tembos (Mosquera, 2004, p. 37).

After abolition of slavery in Colombia in 1852 (Archivo General de la Nación Colombia, 2008) slaves received their legal freedom. Even so, they were the ones who faced the largest restrictions which curtailed economic integration and participation, (if they wished to do so), in the larger Colombian society (See e.g., Escalante, 1964, for full discussion). The cimarrones, started creating their own small towns and began to experience life as legally, free people. Music became an important means to gather people together for every event.

Infusion of African music with Catholic religious practices: Traditionally, slaves were ruled by the same 'Master', under the shadow of religion that Europeans used to practice in the name of King Ferdinand of Aragon and Queen Isabella of Castile, known as the Catholic King \& Queen of Spain. Understandably, the Spanish missionaries brought religious activities accompanied by a considerable amount and range of Spanish, Catholic religious music. Slaves were allowed to bring their drums to the religious services, as part of a Roman Catholic strategy to convert them to Christianity. The slaves responded by playing their drums, and mixing drumming with the sacred Roman Catholic music (Arango \& Valencia, 2011). Perhaps, a subtle strategy of resistance, masked as compliance. Over time, the slaves appropriated the music. It became an important part of the context, so characteristic of this region, examples include: chigualos, velatorios, novenarios, velorio de santo, velorio, alumbramiento, guali, angelito bailao, muertoalegre and so on (Abadía Morales, 1983, p. 221). 
People in the zone of Pacific Littoral have numerous African retentions in for example, music, musical instruments, dance, ritual, folkways and vocabulary; all still preserved within the black communities (Escalante, 1964, p. 172). In like manner, a lot of customs and Spanish music also remain in the communities. A broad repertoire includes, Mazurkas, Polkas, Jotas, Danza, Ronda, Pasillo, and Contradanzas (Marulanda, 1984, p. 210).

According to Octavio Marulanda, the currulao, the focus of attention in this article, arrived in Cartagena de Indias in the 17th Century. This dance was called Danza de esclavos (Slaves' Dance, p. 215). Next, the currulao traveled from North to South within Colombian territories by passing, the province of Antioquia and finally, settling in the Colombian Pacific Coast. Interestingly, the currulao has become the most representative music of the Colombian Pacific lowlands. It can be found as part of the secular music practices, as well as, within religious contexts for special events.

\section{Geographic and economic contexts}

The Pacific coast of Colombia is a zone of 83,170 square kilometers that includes parts of four of Colombia's 'departments': Chocó, Valle del Cauca, Cauca, and Nariño. This entire region is characterized by high humidity due to its higher rainfall, considered one of the highest in the world with an annual average of 4,000 millimeters, and in some places of 12,000 millimeters.

The region remains mostly uninhabited. The majority of people are materially poor. They are marginalized in terms of their separation from the central economic activities, which sustain the Colombian society. 


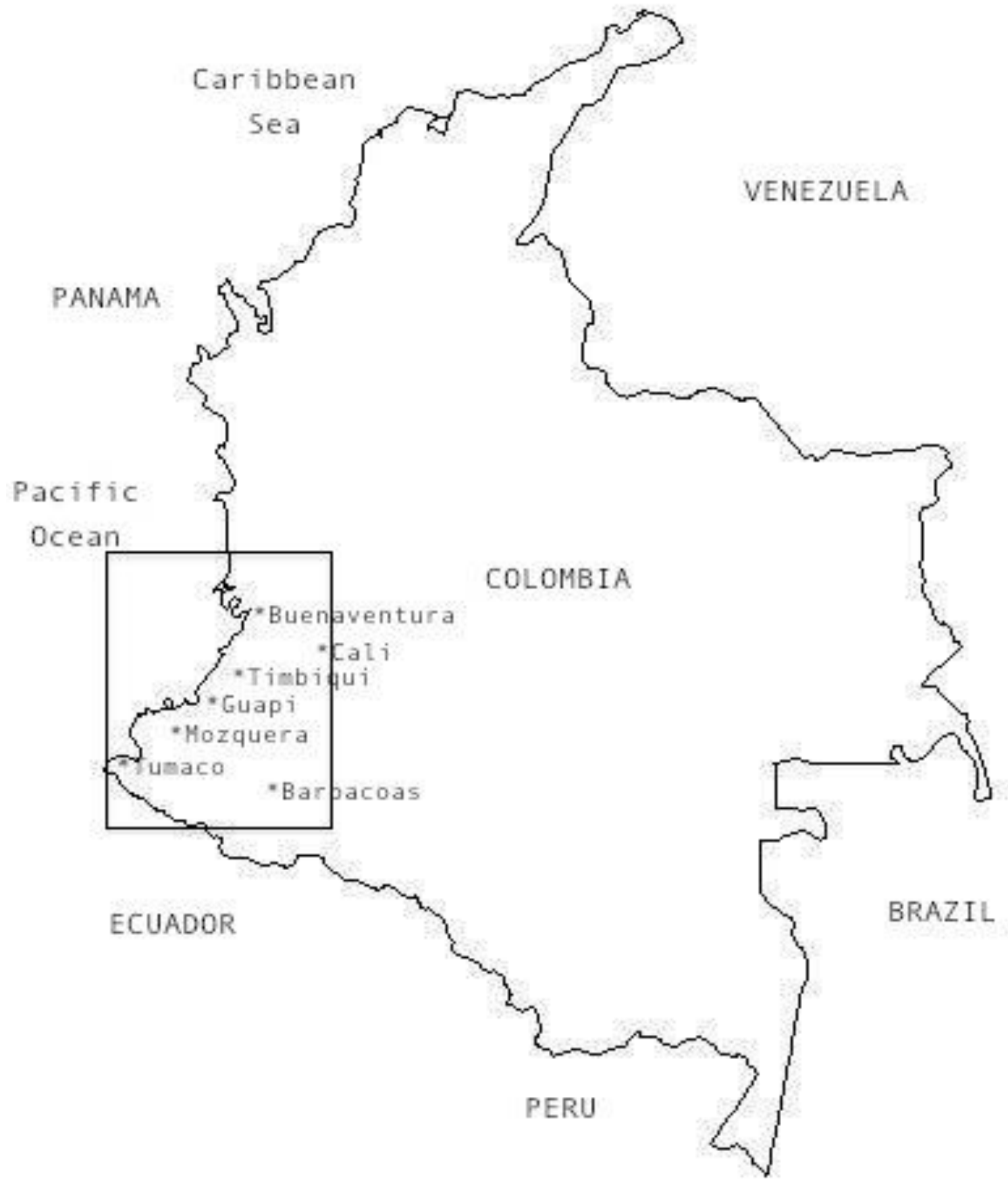

\section{Map: South Colombian Pacific Coast}




\section{Musical and cultural contexts}

There are four different scenarios in which the traditional music of the South Colombian Pacific coast has developed: arrullo, currulao, sometimes called baile de marimba (marimba dance), chigualo, also called velorio de Niño o velorio de angelito (child's funeral or little angel's funeral) and velorio de adulto (adult's funeral). Within the currulao frame there is a genre called currulao or bambuco viejo (old bambuco), (Birenbaum, Convers, Hernández, Martínez, Miñana, Ochoa, Rojas, Sevilla, E., Sevilla, M. \& Tascón, 2008). The next section presents a summary of each type of music.

Arrullo (a lullaby for the Saints): The Arrullo is a religious ceremony in which people often gather to worship Catholic saints, the Virgin Mary and the Christ Child through music. These saints are the benefactors of the people or community, who are pleading for their help. There are two main genres that musicians usually perform and they are known as Juga, and Bunde.

The word "Juga" is derived from the word "fugue" (Abadía Morales, 1983, p. 218). Used in classical music, Johan Sebastian Bach was its greatest exponent. A fugue refers to the way in which two or more voices sing. The juga is one of the most popular musical genres and is wide spread along the Colombian Pacífic coast. Secular and religious events are the scenarios to perform jugas. The marimba de chonta is not the main instrument in the juga. It is performed by the cantaoras (female singers) with bombos (male and female bass drums), cununos (male and female conic drums) and guasás (shakers). This does not mean that the marimba de chonta never plays in the juga. It means that the juga can be played without the marimba de chonta. In a religious context, the juga is sung entirely by women who perform in a call-and-response style. The glosadora (main singer) and the respondedoras (from the verb "to respond") are the main subject in the juga (Ramón, 2010, p. 74).

The bunde is a genre that belongs to common simple meter signatures of $2 / 4,4 / 4$, or $2 / 2$. It is a very simple musical form that embraces numerous tunes from the Colombian Pacific coast, for different purposes (Abadía Morales, 1983).

Currulao or baile de marimba (marimba dance): It is important to clarify that because of their secular nature, the currulao or baile de marimba can be involved in many different kinds of celebrations of daily events. Diverse genres are played in the baile de marimba and they include at least six distinct types: the bambuco/bambuco viejo, and the juga corona bambara negra, among them. The players mentioned below hold different opinions about the music. According to Genaro Torres, a Marimba performer in the municipality of Guapi, for example argues that all baile de marimba are different. Nonetheless, some musicians who live in the municipality of Guapi and its surrounding area believe that many of the genres are similar and differ only in their lyrics (Birenbaum, et al., 2008). Guillermo Rios Benites and Silvino Mina, two marimba performers also from the municipality of Guapi, claim that pango, patacore and bereju (related to the six types of marimba mentioned above) are essentially the same genre.

The currulao or bambuco viejo as a genre has its main protagonist on the marimba de chonta like other genres as well. Its major traits are African and they can be found in the drums 
and responsorial songs. The currulao can also be both sung and performed instrumentally. It can be found in a variety of religious and secular celebrations.

The performance on the marimba de chonta in the currulao is composed by two principal parts: the bordón and the requinta. The bordón is an ostinato pattern played in the marimba lower register as a backbone for the whole song. It has several variations that are played in different moments of the song. The requinta is played in the middle and higher register of the instrument. It is perhaps the most interesting aspect of the currulao genre. Different patterns of the requinta played on the marimba de chonta could be included in each song, and these patterns are seen as the hallmark of each marimbero (performer). The currulao is rich rhythmically. In listening to the music, one can see two-measure isorhythm pattern where the harmony is changing each one measure, one in tonic, and one in dominant (Birenbaum, et al., 2008).

The dance: The currulao as a dance is well documented by Michael Birenbaum Quintero who states that "The male dancers, each intent on his partner, whirl their handkerchiefs again, and stamp with their bare feet on the wooden floor following the rhythm of the cununo to attract the attention of their partners. He may approach her, opening his arms as if to entrap her, as she twirls and then retreats, if she approaches him, he will do the same" (Quintero, 2009, p. 3).

Chigualo or velorio de Niño or velorio de angelito (child's funeral or little angel's funeral): The Chigualo or Bunde is a funeral ritual in which the music moves from depicting the grief and pain for the loss of a family member; it changes into rejoicing and happiness because of the entrance of the child's soul into the kingdom of spirits (Abadía Morales, 1983). It is a ritual celebration upon the death of a child who is less than five years. It is believed that his/her soul is pure. Therefore, he/she is an angel. This ritual often turns into a celebration, which could involve alcoholic beverages, card games, dancing, and singing. Bundes and lullabies are the most common genres used in the Chigualo celebration.

Velorio de adulto (adult's funeral): When an adult dies, celebrations occur to help the soul to leave the body. Understandably, these celebrations are usually a very tragic event for the family of the deceased. Because the deceased's soul is believed to be impure, the bereaved family prays for nine days. Prayers are accompanied by songs that are known as alabaos (praise songs), which are performed a cappella by the cantaoras, but in some occasions bombos, cununos, and guasás are played (Birenbaum, 2008). It is important to note that usually the marimba de chonta is not played in this celebration.

Interestingly, in the Colombian Pacific coastal region, the Afro-Colombian culture does not have rigid distinctions and clear boundaries between secular and religious contexts. Accordingly, it is difficult to determinate when a religious context ends, and when a secular context starts.

The music on the multimedia and written explanation identify different patterns of the currulao music and different interpretations by each of the twenty musicians from municipalities close to Guapi. It is important to note that differences in performance practices are quite prevalent.

Cultural and Pedagogical Inquiry, Fall 2016, 8(2), pp. 72-82

ISSN 1916-3460 @ 2016 University of Alberta

http://ejournals.library.ualberta.ca/index.php/cpi/index 
The principal differences lie in the revueltas (ornamentations and variations of the requinta) played by each marimbero (marimba player). The requinta is everything played in the middle high register of the marimba. Therefore, the revueltas are part of the requinta. These revueltas are the result of many years of experience playing currulao. They are regarded as a hallmark of an individual marimbero. One can often recognize who is playing the marimba by listening to the revueltas. A parallel can be drawn with the ease of recognition of the distinctive research and writing styles of well established, researchers in other disciplines.

As one hears in the multimedia and reads the text, one notes that the performers have a variety and range of interpretations, which depict the richness of the African Colombian music inherited by oral tradition. The musicians presented in the multimedia and larger study, are from the same region and yet, each has his/her own interpretation of how the currulao should be played. As hinted in the discussion, some have specific views concerning whether the music is the same or different. Nevertheless, in a similar manner to qualitative researchers' views, no interpretation is absolutely right. None is right in a deterministic sense since each musician's approach to the music is unique and equally valuable.

Due however, to ease in communications, there has been the enormous impact of modern music (from north and southern countries) on Colombian youth. Traditional music of the Colombian Pacific coastal region has been permeated and bombarded constantly, by different and wide ranging, musical genres. Sooner or later, changes in the currulao will be significant enough that its original, distinctive features will be lost. It scarcely needs to be said that preserving the currulao music will yield benefits for everyone and anyone who ventures into this field of Colombian Pacific music.

Scholarly musicians might wish to approach the currulao music with warmer ears, eyes and hearts, while continuing to search for a better understanding of this specific and unique musical genre. Hopefully, my research can be a starting point for anyone who wants to delve into the music of the Colombian Pacific coast and perhaps wishes to become involved, even immersed with the work of traditional musicians, composers, performers, singers and dancers. 


\section{Endnotes and Appendix: Information included and excluded}

1. For detailed analyses of the different musical variations of each musician's performance, consult my research. Performers who participated in the study are: Alejandro and Carlos Riascos Castillo, Angel Isaac Ocoro, Antonio Mina, Carlos H Riascos, Cenen A Hurtado, Francisco Javier Cachimbo, Genaro Torres Solis, Francisco Torres Solis, José Antonio Torres, Iber Gómez, Jaime A Ramos, Javier Balanta, Jhoany Mina Patiño, Jhon Fransico Gallo Ruíz, Libardo Rosero, Lucas Estevan Copete, Nestor Alfonso Castro, Wilmer Vente, Yeiner Albeiro Orobio Solis, Yeison A Mina, Carlos H. Riascos.

2. Understandably, the detailed musical scores and analyses, meant for trained musicians have not been included in this CPI article. The detailed examination of examples of patterns identified in each musician's music has also not been included.

3. The study itself is based on taping a series of performances made in a controlled environment. The video and audio files belong to the author.

4. The following discussion is also meant primarily, for musicians. It is included, since it gives specific links of the musical instruments adapted by the cimarrones from different African cultures. Furthermore, it gives meaning to the series of photographs identified at the start of the multimedia. Important to note too, that the seemingly, simple musical instruments, in analysis indicate the sophistication of the music.

\section{Typical Instrumentation of the Marimba de Chonta group}

The ensemble is composed of: one marimba de chonta, two cununos, two bombos, and five guasás (the number may vary) played by the cantaoras (female singers). This typical group can be used to perform a wide repertoire of secular and religious music.

Marimba de chonta: The marimba de chonta is a xylophone made by a row of hardwood bars of chonta (palm tree) of different lengths and widths. The number of keys may vary from fourteen to as many as twenty-four. Under these pieces of wood hang different pipes of bamboo that function as resonators. The marimba de chonta is usually found suspended from the ceilings of the "houses" where they are played. The marimba is the most representative instrument in the southern Pacific region, and it is the main instrument in the currulao. This instrument is used to play a variety of rhythmic subgenres derived from the currulao such as: juga, amanecer or andarele, bambara negra, berejú, caramba, madrugada, makerule, pango, patacore, etc. The performers are called marimberos and the marimba de chonta could be played by two of them: one player known as bordonero, in the lower register playing the bordón part, and the other known as a tiplero or requintero, in the middle and high register playing the requinta or tiple part. In the currulao performance the marimba performers usually sing and play.

Cununo: The cununos are single-membrane drums. They are made out of wood, possess a conical/barrel shape, and measure approximately 60 to 90 centimeters high and 35 to 45 centimeters at their waist. The bottom is closed with a round piece of balsa wood. Two cununos are found in a typical group of marimba de chonta: one macho (male) and one hembra (female). The cununo macho (male cununo) is taller than the cununo hembra (female cununo) and it is tuned lower. Usually the cununo macho plays the basic pattern but often depending of the mood, the cununero macho (male cununo performer) improvises. The cununo hembra (female cununo)

Cultural and Pedagogical Inquiry, Fall 2016, 8(2), pp. 72-82

ISSN 1916-3460 () 2016 University of Alberta

http://ejournals.library.ualberta.ca/index.php/cpi/index 
is tuned higher than the cununo macho, and it is somewhat smaller than the cununo macho. This drum plays a very complex role in the currulao music: though it has its own basic pattern, most of the time the cununo hembra plays freely.

Bombo: The bombo is a double-headed bass drum. Like the cununo, there are two kinds of bass drums: one bombo macho or golpeador (male drum or "striker"), and one bombo hembra or arrullador (female drum or "tranquilizer"). The bombo macho is bigger than the bombo hembra, and it is tuned lower. Usually the performers are called bomberos (bombo performers). They are cylindrical drums made of balsa wood, with their ends covered with membranes (parches). Each of these membranes are made from different kinds of skin: one is made of tatabro (wild boar) skin, and the other is made of venado (deer) skin. Although both membranes are played, the tatabro skin membrane is struck less often. Bombos are played with two mallets, and one of these has its end covered with a piece of cloth. The basic pattern of bombo macho gives the currulao its characteristic sound with the open tone on the fifth eight note of a $6 / 8$ metre.

Guasá: The guasá is a shaker made of dried bamboo, which generally measures fifty centimeters in length and eight centimeters in diameter. It has hardwood nails driven through the side of the resonance chamber and is filled with seeds. In a performance between five and six guasás are used at the same time. The guasás are played mainly by cantaoras (female singers). 


\section{References}

Abadía Morales, G. (1983). Compendio General de Folklore Colombiano. Bogota: Banco Popular.

Arango, A. M. \& Valencia, L. (2009). La chirimia chocoana: Asimilación y reafirmación. Revista Acontratiempo 13. Retrieved from http://www.bibliotecanacional.gov.co/tools/marco.php?idcategoria=39295

Archivo General de la Nacion Colombia. (2008). La esclavitud en Colombia: Yugo y libertad - Testimonios documentales 1553 - 1859. Retrieved from http://www.archivogeneral.gov.co/noticias/agn-conmemora-el-mes-de-la- herenciaafricana-en-quibdó

Arcila, Carlos. (2012). A Multimedia Stylistic Analyis of the Marimba de Chonta, Guapi, Cauca, Colombia. Unpublished thesis, Department of Music, York University.

Birenbaum, M. (2009). Currulao, the marimba dance. Retrieved from http://www.lameca.org/dossiers/afro_colombian_music/eng/p3.htm

Birenbaum, M., Convers, L., Hernández, O., Martínez, A., Miñana, C., Ochoa, J., Rojas, A., Sevilla, E., Sevilla, M. \& Tascón, H. (2008). Componente investigativo del plan ruta de la Marimba. Cali: Pontificia Universidad Javeriana.

Escalante, A. (1964). El negro en Colombia. Bogota: Universidad Nacional de Colombia, Facultad de Sociología.

Lopez, J. (1980). Musica y folklore de Colombia. Bogotá: Plaza y Janes.

Martínez, A. G. (2005). Toda Colombia. Retrieved from http://www.todacolombia.com/geografia/regionesnaturales.html

Marulanda, O. (1984). El folclor de Colombia: Práctica de la identicad cultural. Bogota: Artestudio Editores.

Mozquera, S. A. (2004). La carimba, la carimba candente, la carimba sobre la piel: Antroponimia Afrochocoana. Quibdó: Universidad Tecnológica del Chocó "Diego Luis Córdoba".

Ramón, A. (2010). Colombian folk music in an international context: An overview. Unpublished Master's thesis. Reykjavík: Iceland Academy of the Arts. 